\title{
Study on CCR5 Receptor Antagonists as an Anti-Prostate Cancer: Inhibition Activity, QSAR and Molecular Docking
}

\author{
Nursamsiar $^{1,2}$, Lina Nurfadhila ${ }^{1}$, Iman S. Pratama ${ }^{1}$, Aiyi Asnawi ${ }^{1 *}$, Slamet I. Surantaatmadja ${ }^{1}$ \\ ${ }^{I}$ School of Pharmacy, Bandung Institute of Technology, Jalan Ganesha 10, Bandung, 40132, Indonesia. \\ ${ }^{2}$ Sekolah Tinggi Ilmu Farmasi Makassar, Jalan Perintis Kemerdekaan km 13,7 Daya, Makassar, 90432, Indonesia.
}

Received: 29 October 2014 / Accepted: 30 November 2014

\begin{abstract}
:
Chemokine receptor CCR5, a G protein-coupled receptor (GPCR), has been shown as a viable target in drug discovery due to its involvement in HIV entry and cancer. In HIV pathogenesis, CCR5 acts as an essential co-receptor for HIV invasion into host cells; whereas in cancer, it provides a pro-inflammatory environment promoting cell invasion and proliferation in several cancers. Within those cancers, prostate cancer specimens have also been shown to over express CCR5. Thus, development of CCR5 antagonists may provide novel prostate cancer therapy. Several small molecule CCR5 antagonists have been developed as anti-prostate cancer such as anibamine and carboxymethyl-glucan (CM-G). In this paper, we designed a series of $\mathrm{N}-(5-(1-$ benzylpiperidin-4-yl)-2-hydroxyphenyl)formamide derivatives as anti-prostate cancer. The developed model was conducted based on molecular docking studies and validated by standard QSAR parameters. The QSAR analysis using a series of $\mathrm{N}$-(5-(1-benzylpiperidin-4-yl)-2-hydroxyphenyl)formamide derivatives was successfully carried out to build a statistically significant model possessing a good correlative and predictive capability for the inhibition CCR5 antagonists. This analysis could be help in developing potential inhibition candidates for an anti-prostate cancer. Docking simulation was performed by AutoDock 4.1.5.6. The results showed that the main parameters of QSAR equation for inhibition CCR5 activity were AM1_dipole, AM1_HOMO, ASA_H, AM1_E and $\mathrm{mr}$ with $\mathrm{r}^{2}, \mathrm{q}^{2}$ and $\mathrm{F}$ of $0.865 ; 0.997216$ and 4.233015 , respectively. The docking results revealed that $N$-(5-(1-benzylpiperidin-4-yl)-2-hydroxyphenyl) formamide and its derivative can interact to binding sites of the studied CCR5 receptor formed hydrogen bond with Tyr37, Trp86, Tyr108, Phr182, Gln194, Ile198, Tyr251, Glu283, and Met287. They have the same pattern of hydrogen bonds with the known binding ligands maraviroc (PDB ID 4MBS) for CCR5.
\end{abstract}

Key words: CCR5, docking, maraviroc, prostate, QSAR

\section{Introduction}

Health reproduction is ones of main focuses to improve health of Indonesia people [1]. Currently prostate cancer is the second of the most common non-cutaneous solid cancer in men on the world. Approximately 25.3 of 100,000 men will suffer from prostate cancer [2]. Indonesian Urology and Oncology Association reported than $50.5 \%$ end state prostate cancer in men or similar with 490 of 971 along 2006 until 2010 [3]. Several prostate cancer therapies exist, but beneficially limited to early stages of the disease. Upon the onset of prostate cancer metastasis, there are no significantly effective therapies. Therefore, exploiting CCR5 induced cancer cell invasion and proliferation could be a useful therapy to avoid the progression of prostate cancer at later stages. In order to do so, CCR5 antagonist specifically targeting prostate cell proliferation and invasion need to be developed. Current treatment for cancer is purposed to cure symptom and improving quality of life. Treatment

\footnotetext{
*Corresponding author: Aiyi Asnawi
}

E-mail: aiyiasnawi@fa.itb.ac.id for prostate cancer commonly uses androgen replacement therapy. Unfortunately, undesirable effect showed significant numbers in men, for instance impotency, loss of libido, and gynecomastia [4]. Therefore, looking for new drug target of prostate cancer therapy is still need.

Chemokines are small soluble molecules that are best known for their potent abilities to induce cellular migration [5]. Chemokine receptor CCR5, a G Protein-Coupled Receptor (GPCR), has been shown to be a viable target in drug discovery due to its involvement in cancer. CCR5 primarily functions through interaction with endogenous small cytokines (chemokine) which include CCL5. CCL5 expression has been correlated to the progression of several cancers, potent inducer of tumor cell migration and invasion, host anti-tumor response are, inflammation. Chronic inflammation has been recognized as a risk factor in a variety of human cancer, including prostate. Prolonged inflammation is thought to potentiate carcinogenesis by providing micro-environment for development and growth of cancer [6]. Development of CCR5 antagonists may provide 
novel prostate cancer therapy. Several small molecule CCR5 antagonists have been developed as anti-prostate cancer. In vitro study of $N$-(5-(1-benzylpiperidin-4-yl) -2-hydroxyphenyl) formamide derivatives shown potential CCR5 antagonist with inhibition coefficient below $40 \mu \mathrm{M}$ [6]. These available experimental data can be used to guide the modeling of CCR5. In the present study, we used an approach docking methods to investigate the antagonist-CCR5 interaction mechanism and the structure-activity relationship of the antagonists. Structure modification should can improve bind affinity ligand-receptor that shown by lower amount of predictive $\mathrm{IC}_{50}$. The aim of this research was to determine predictive $\mathrm{IC}_{50}$ of $N$-(5-(1-benzylpiperidin-4-yl)- 2-hydroxyphenyl) formamide derivatives and ligand-receptor CCR5 binding energy using QSAR analysis and molecular docking.

Best QSAR equation was used to obtain the $\mathrm{IC}_{50}$ of new compounds. Lastly, docking study of the interaction with receptors CCR5 using software AutoDock 4.1.5.6 was examined.

\section{Experimental}

The research method included the preparation of a three-dimensional model of the structure of the compound using the software Gaussian 09W. Then, the model was used to measure the value of the predictor using the software Molecular Operating Environment (MOE 2009.10) and performed statistical analysis using SPSS Statistics 21.0 software to obtain QSAR equation that best meet the criteria.

Preparation of three-dimensional model of the structure of compounds was done by drawing the structure of molecules in two-dimensional plane and the addition of hydrogen. Three-dimensional structure of molecules was further optimized by Hartree-Fork Ground State method with basis set 3-21G.

The predictor models were selected with criteria of $r \geq 0.8$ and the $\mathrm{F}$ table/ $\mathrm{F}$ calculated $\geq 1$ with a significance level of $95 \%$. $\mathrm{q}^{2}$ value of each predictor models that have met the criteria was calculated and that with largest $\mathrm{q}^{2}$ was selected. LOO-CV was done by eliminating outlier's compounds in order to obtain the best QSAR equation [7].

Design of new compounds was done by selecting 17 compounds of the series CCR5 inhibitor based on research by Arnatt et al [6] as the parent compound (Figure 1). Parent compound was substituted with variation of substituents on the aromatic ring structure by Topliss scheme

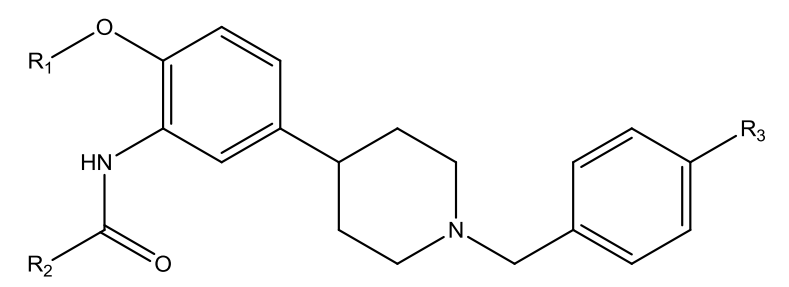

Figure 1. Lead structure of $\mathrm{N}-(5-(1-$ benzylpiperidin -4-yl)-2-hydroxyphenyl) formamide [6].

\section{Results and Discussion}

Twenty four compounds were structurally geometrical optimized and further their predictors were calculated. The value of each compound was statistically analyzed to obtain the best QSAR equation that describes the influence of certain predictors of the CCR5 inhibitor activity. Statistical analysis of the first step was through multilinear regression analysis with $\mathrm{IC}_{50}$ of each compound trial as the dependent variable (Y) and the value of each predictor as the independent variable $(\mathrm{X})$. Multilinear regression was done by combining $\mathrm{IC}_{50}$ with 4 and 5 predictors. In general, the regression equation can be accepted on QSAR study if the correlation coefficient ( $r$ ) to be around or better than 0.8 , and if the value of $F$ indicates a significance level better than $95 \%$ [8]. 252 combinations showed no fulfillment of these criteria but the highest one of them still can use with $r^{2}=0.534$. Seventeen compounds were obtained after $\mathrm{Z}$ score analysis $\mathrm{r}^{2}$ value $0.8423, \mathrm{q}^{2}=0.997$, and $\mathrm{F}$ ratio to the $\mathrm{F}$ table value 5.077192. The $\mathrm{q}^{2}$ values were calculated by performing LOO-CV to all models with $\mathrm{R}$ value of $\geq 0.8$ and $\mathrm{F}$ ratio to the $F$ table value of $\geq 1.0$. From the calculated value of $\mathrm{q}^{2}$, the best QSAR equation in this study was $\log \mathrm{IC}_{50}=$ $-4.6394+0.1729 *(A M 1$ dipole $)-0.5271 *($ AM1_HOMO) $-0.0106 *($ ASA_H $)+0.000015 *($ AM1_E $)+0.8598 *(\mathrm{mr})$.

Best QSAR equation can be used to calculate the closeness between predicted $\mathrm{IC}_{50}$ and observed $\mathrm{IC}_{50}$. This can be done by plotting both values in graph (Figure 2). 


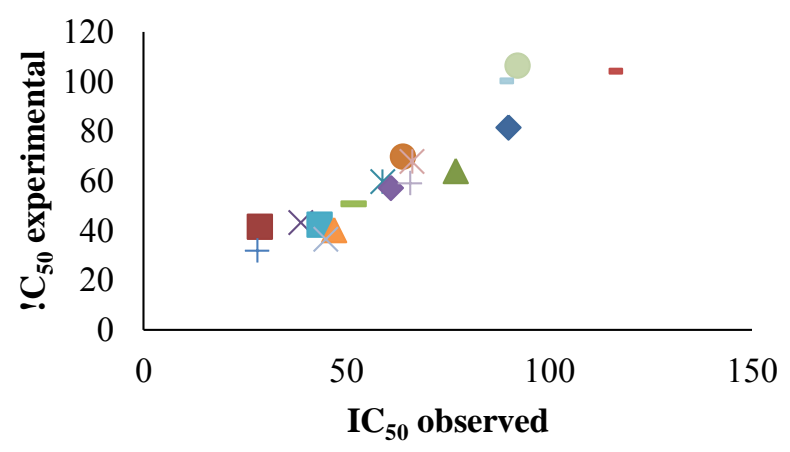

Figure 2. Plot of observed versus predicted activity by QSAR.

Design of new compounds can be done by first selecting a compound of the series CCR5 inhibitor. Compound (17) $\left(\mathrm{IC}_{50}=28.0 \pm 3.1\right)$ was chosen as the parent compound. The purpose of the design of new compounds was to discover new compounds with better activity than the parent compound and the whole series CCR5 inhibitor. Topliss scheme for aromatic substituent was used for design of new compounds by combining 2 substituents (X and Y). Substituent replacement was done by combining 2 identical and different substituents in sequence. The used substituents were $-\mathrm{Cl},-\mathrm{OMe},-\mathrm{CH}_{3}$, -tert. but (tertiary butyl), $-\mathrm{CF}_{3},-\mathrm{NMe}_{2},-\mathrm{NH}_{2}$, and $-\mathrm{F}$ [9].

Table 1 stated that the most influence predictor were AM1_HOMO (correlation coefficient $=0.1938)$ and AM1_HOMO interdependence with $\mathrm{mr}$ (correlation coefficient $=0.2143$ ). Therefore, addition of groups in designing new compounds was done base on the value of AM1_HOMO and $\mathrm{mr}$ in order to obtain a better $\mathrm{IC}_{50}$ values. Furthermore, the value of
ASA_H and AM1_E were examined to other parameter as important de criptor for this QSAR.

Design of the new compound resulted 252 compounds. All the compounds were then optimized with Gaussian 9.0 semi-empirical Hartree-Fork Ground State method with basis set $3-21 \mathrm{G}$. The values of each predictor newly designed compounds were used in the best QSAR equation to find prediction of $\mathrm{IC}_{50}$ values. The two compounds with lower $\mathrm{IC}_{50}$ values in comparison to parent compound are shown in Figure 3.<smiles>CCOc1ccc(C2CCN(Cc3ccc(OC)cc3)CC2)cc1NC(=O)c1ccccc1</smiles>

(9)<smiles>COc1ccc(C2CCN(Cc3ccc(C(F)(F)F)cc3)CC2)cc1NC(=O)c1ccccc1</smiles>

(17)

Figure 3. Two new compounds with higher predicted activity $\left[\mathrm{IC}_{50}\right.$ of compound $(9)=28.7$ and compound $(17)=28.0$.

The docking study of the new compounds with its receptor was estimated using software AUTODOCK 4.1.5.6. Result of $\Delta G$ value, total hydrogen bonding and bond distance was done by Discovery Studio.

Table 1. Correlation matrix forsimulated annealing (ovarian) best model

\begin{tabular}{lrrrrrr}
\hline & AM1_DIPOLE & AM1_HOMO & ASA_H & \multicolumn{1}{c}{ AM1_E } & \multicolumn{1}{c}{ mr } & \multicolumn{1}{l}{$\mathrm{IC}_{50}$} \\
\hline AM1_DIPOLE & 1 & 0.7660 & 0.0747 & -0.0234 & 0.1394 & 0.2835 \\
AM1_HOMO & & 1 & -0.0181 & 0.0147 & 0.2143 & 0.1938 \\
ASA_H & & & 1 & 0.9399 & -0.5906 & 0.3825 \\
AM1_E & & & & 1 & -0.6606 & 0.4696 \\
mr & & & & & 1 & -0.1819 \\
IC $_{50}$ & & & & & & 1 \\
\hline
\end{tabular}


Table 2. Molecular docking interaction of Maraviroc (native ligand), compound (9), and compound (17) in CCR5 inhibitor (PDB ID $4 \mathrm{MBS}$ )

\begin{tabular}{|c|c|c|c|c|c|c|c|c|}
\hline No. & Compound & $\begin{array}{c}\Delta G \\
(\mathrm{kcal} / \mathrm{mol})\end{array}$ & $\mathrm{Ki}$ & $\begin{array}{c}\text { No. } \\
\text { H-bonds }\end{array}$ & $\begin{array}{l}\text { Proton } \\
\text { Donor }\end{array}$ & $\begin{array}{l}\text { Proton } \\
\text { Acceptor }\end{array}$ & $\begin{array}{c}\text { H-bonds } \\
\text { length } \\
(\AA)\end{array}$ & $\begin{array}{c}\text { Interacting } \\
\text { Residues }\end{array}$ \\
\hline 1 & $\begin{array}{l}\text { Native } \\
\text { Ligand }\end{array}$ & -12.75 & $447.97 \mathrm{pM}$ & 2 & NH-ligand & O-Glu283 & 3.032 & $\begin{array}{c}\text { Tyr37, Trp86, Tyr89, } \\
\text { Tyr108, Phe109, } \\
\text { Phe112, } \\
\text { Phr182, Ys191, Gln194, } \\
\text { Thr195, Ile198, Trp248, } \\
\text { Tyr251, Leu255, } \\
\text { Glu283, } \\
\text { Thr284, Met287 }\end{array}$ \\
\hline 2 & $\begin{array}{c}\text { Compound } \\
\text { (9) }\end{array}$ & -8.91 & $295.36 \mathrm{nM}$ & 1 & NH-ligand & O-Glu 283 & 3.000 & $\begin{array}{l}\text { Tyr37, Trp86, Tyr89, } \\
\text { Ala90, Tyr108, Phe109, } \\
\text { Phr182, Ys191, Gln194, } \\
\text { Thr195, Ile198, Tyr251, } \\
\text { Glu283, Thr284, Met287 }\end{array}$ \\
\hline 3 & $\begin{array}{c}\text { Compound } \\
\text { (17) }\end{array}$ & -9.48 & $112.55 \mathrm{nM}$ & 4 & $\begin{array}{l}\text { NH- ligand } \\
\text { OH-Tyr108 } \\
\text { NH-Trp86 } \\
\text { OH-Tyr251 }\end{array}$ & $\begin{array}{l}\text { O-Glu } 283 \\
\text { O-ligand } \\
\text { O- ligand } \\
\text { O-ligand }\end{array}$ & $\begin{array}{l}2.764 \\
3.231 \\
3.228 \\
1.705\end{array}$ & $\begin{array}{c}\text { Tyr37, Val83, Trp86, } \\
\text { Tyr108, Phe109, } \\
\text { Ser180, } \\
\text { Phr182, Gln194, Ile198, } \\
\text { Trp248, Tyr251, } \\
\text { Glu283, } \\
\text { Met287 }\end{array}$ \\
\hline
\end{tabular}
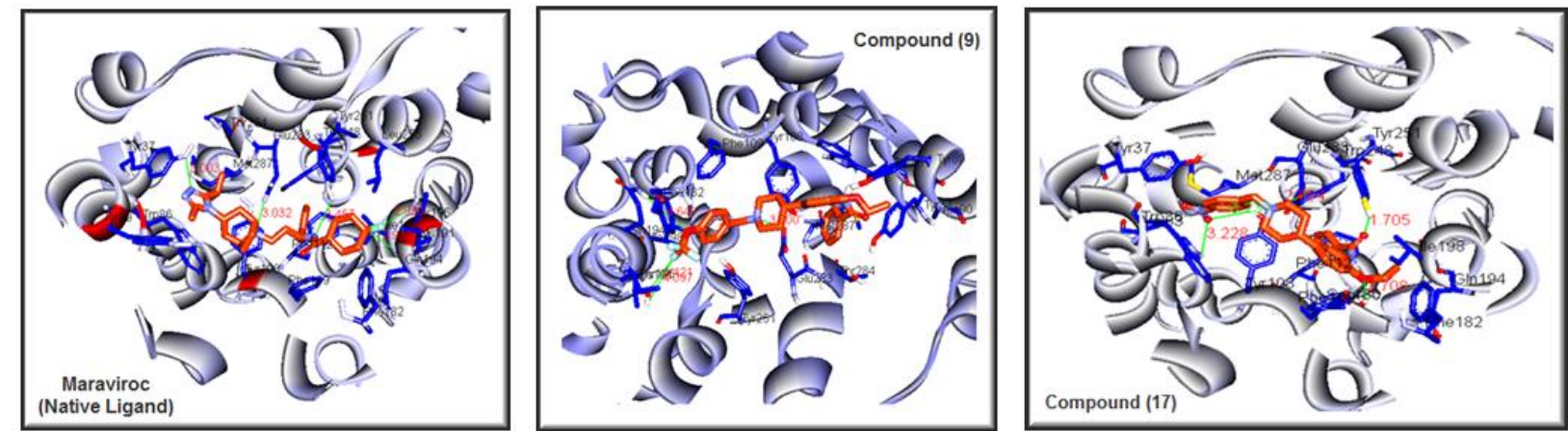

Figure 4. Docked poses for maraviroc (native ligand), compound (9), and compound (17). Ligands are shown in red balls and sticks, possible interacting residues in green sticks.

Compounds (9) and (17) were observed to show best docking scores where the best least low energy of -8.91 $\mathrm{kcal} / \mathrm{mol}$ and $-9.48 \mathrm{kcal} / \mathrm{mol}$, respectively. Number of hydrogen bond interactions was observed in the docking complexes of compound (9) and (17) and native ligand of 2, 1, and 4, respectively. The docking results revealed that compound (9) and (17) can interact to binding sites of the studied CCR5 receptor formed hydrogen bond with Tyr37, Trp86, Tyr108, Phr182, Gln194, Ile198, Tyr251, Glu283, and Met287. They have the same pattern of hydrogen bonds with the known binding ligands maraviroc (native ligand) (PDB ID 4MBS) for CCR5 (Table 2) and (Fig. 4).

The region of the CCR5 Nt spanning amino acids 2-18 contains all of the residues were shown to be important for viral entry and Tyr3, Tyr10, and Tyr14 were required for optimal co-receptor function, whereas Tyr15 was interchangeable with Phe-15 [10]. Therefore, two desinged compounds (compound (9) and (17)) were potential candidates as new CCR5 inhibitor. 


\section{Conclusions}

In conclusion, QSAR model equation stated $\mathrm{IC}_{50}=$ $-4.6394+0.1729 *$ (AM1_dipole) $-0.5271 *$ (AM1_HOMO) $-0.0106 *($ ASA_H $)+0.000015 *$ $($ AM1_E $)+0.8598 *(\mathrm{mr}), \mathrm{q}^{2}=0.9972$. Compound (9) and (1) $\overline{\mathbf{1 7}})$ were potential candidates as new CCR5 inhibitor with better activity prediction than that of the parent compound.

\section{References}

[1] Direktorat Kesehatan Ibu, Program Kesehatan Reproduksi dan Pelayanan Integratif di Tingkat Pelayanan Dasar, 2008, Jakarta: Departemen Kesehatan.

[2] V. Nelen, Epidemiology of Prostate Cancer in Prostate Cancer, 2007, Berlin: Springer Berlin Heidelberg, 1.

[3] J.M. Kolesar, Prostate Cancer in: DiPiro, J.T., R.L. Talbert, G.C. Yee, G.R. Matzke, B.G Wells, and L.M. Posey (Eds.), Pharmacotherapy A Pathophysiologic Approach, Sixth Edition, 2005, New York: The Mc-Graw Hill Companies, Inc. 2428.

[4] C. Balmer, Prostate Cancer in: R. A. Helms, D. J. Quan, E. T. Herfindal, and D. R. Gourley (Eds.) Textbook of Therapeutics Drug and Disease Management, Eighth Edition, 2006, Philadelphia: Lippincott Williams and Wilkins, 2474.
[5] P. Weitzenfeld and A. Ben-Baruch, The chemokine system, and its CCR5 and CXCR4 receptors, as potential targets for personalized therapy in cancer, Cancer Letters, 352(1), 2014, 36-53.

[6] C.K. Arnatt, S.A. Zaidi, Z. Zhang, G. Li, A.C. Richardson, J.L. Ware, and Y. Zhang, Design, syntheses, and characterization of pharmacophore based chemokine receptor CCR5 antagonists as anti-prostate cancer agents, European Journal of Medicinal Chemistry, 69, 2013, 647-658.

[7] M.C. Sharma, S. Sharma, P. Sharma, A. Kumar, Comparative QSAR and pharmacophore modeling of substituted 2-[2-dimethylamino) ethyl]-1, 2-dihydro-3H-dibenz de,h]isoquinoline-1,3-diones derivatives as anti-tumor activity, Med. Chem. Res., 22, 2013, 5772-5788.

[8] P. Bultinck, H.D. Winter, W. Langenaeker, J.P. Tollenaere, Computational Medicinal Chemistry for Drug Discovery, Marcel Dekker Inc., New York, 2004, 642 - 643.

[9] H.J. Smith, H. William, Introduction to the Principles of Drug Design and Action, CRC Press, Boca Raton, 2005, 170-190.

[10] E.G. Cormier, M. Persuh, D.A.D. Thompson, S.W. Lin, T.P. Sakmar, W.C. Olson, and T. Dragic, Specific interaction of CCR5 amino-terminal domain peptides containing sulfotyrosines with HIV-1 envelope glycoprotein gp120, Proc. Natl. Acad. Sci. USA, 97(11), 2000, 5762-5767. 